\title{
Article \\ Drawing Lessons When Objectives Differ? Assessing Renewable Energy Policy Transfer from Germany to Morocco
}

\author{
Karoline Steinbacher \\ Environmental Policy Research Centre (Forschungszentrum für Umweltpolitik), Freie Universität Berlin, 14195 Berlin, \\ Germany; E-Mail: karoline.steinbacher@fu-berlin.de
}

Submitted: 26 October 2014 | In Revised Form: 24 January 2015 | Accepted: 23 February 2015 |

Published: 12 May 2015

\begin{abstract}
Given the tremendous energy challenges Morocco faces, and its potential role as an exporter of green electricity to Europe, the country has been particularly targeted by Germany's efforts to promote the uptake of renewable energies abroad. This paper explores whether ideas and policies in the field of renewable energy effectively traveled through transfer channels established between Germany and Morocco. In particular, the question of how Morocco's policy objectives shaped the result of transfer processes is discussed, shedding light on a currently under-researched determinant for policy transfer. Drawing upon forty-five semi-structured interviews with Moroccan, German, and international stakeholders, as well as card-ranking exercises, the article provides first-hand insights into the dynamics and drivers of Morocco's "energy transition". Findings presented in the article show that differing policy objectives did not preclude the transfer of ideas between Germany and Morocco, but shaped its outcome with regard to policy instrument selection. While basic policy orientations in favour of renewable energies were facilitated by transferred knowledge, a perceived incompatibility between domestic policy objectives and the policy instruments used in the foreign model led to selective lesson-drawing from the German example. This finding underlines the importance for "senders" who wish to actively promote sustainable energy policies abroad to adapt outreach strategies to the policy objectives of potential followers.
\end{abstract}

\section{Keywords}

diffusion; Energiewende; energy transition; Germany; Morocco; policy transfer; policy objectives; renewable energy

\section{Issue}

This article is part of a regular issue of Politics and Governance, edited by Professor Andrej J. Zwitter (University of Groningen, The Netherlands) and Professor Amelia Hadfield (Canterbury Christ Church University, UK).

(C) 2015 by the author; licensee Cogitatio (Lisbon, Portugal). This article is licensed under a Creative Commons Attribution 4.0 International License (CC BY).

\section{Introduction}

Understanding what drives and shapes the diffusion and transfer of sustainable energy policies is highly relevant at a time when numerous countries in the world find themselves at energy policy crossroads and look for inspiration abroad. Among potential determinants for the transfer of principles, policies, or instruments between "sending" and "receiving" countries, this article takes a closer look at the role of policy objectives. For both senders and receivers (or "leaders" and "followers", as they are more commonly referred to in the literature), understanding the impact of similar or differing policy objectives on the prospects of policy transfer is essential. For followers interested in drawing lessons, a critical evaluation of the fit between domestic policy objectives and foreign models is necessary to avoid transfer-related policy failure (Dolowitz \& Marsh, 2000; Pegels, 2014, p. 184). Pioneers can use these insights to promote learning from their policies more effectively by taking into account the goals followers primarily pursue.

Following the widely used definition by Dolowitz and Marsh (2000, p. 5), transfer is understood in this paper as a process "by which knowledge about policies, administrative arrangements, institutions and ideas in one political setting (past or present) is used in the de- 
velopment of policies, administrative arrangements, institutions and ideas in another political setting". Consequently, the aim in this paper is not to test whether Morocco "copied" the German Energiewende, but to enquire how policy objectives shaped the use of evidence from this example and of information provided by German transfer agents in the Moroccan debate and in policy decisions for renewable energy in the electricity sector. Focusing on policy objectives as a potential determinant for transfer is particularly relevant here: while many factors known to facilitate policy transfer (communication channels, structural incentives, the presence of German transfer agents) come together in the case of Morocco and Germany, priorities pursued through an increase of renewables in the electricity mix differ, as discussed below.

The German energy transition-or Energiewende-is one of the most prominent examples of an energy transition (Rat für nachhaltige Entwicklung, 2013; Weidner \& Mez, 2008), making it a likely potential source of inspiration for countries considering changes to their own energy system. Although recent studies reveal considerable interest in the German energy transition or "Energiewende" from observers abroad (GIZ, 2012a; Konrad-Adenauer-Stiftung, 2013, 2014), little is known about the extent to which lessons are effectively drawn from this example and how active policy promotion by Germany impacts decision-making in other countries.

Assessing transfer from the German energy transition is rendered challenging given the multitude of policies, programs and instruments in place to achieve its targets for renewable energy $(80 \%$ of the electricity mix by 2050), C02-reduction ( $80-95 \%$ by 2050), the reduction of primary energy consumption ( $50 \%$ by 2050 ), and nuclear phase-out (to be completed by 2022). The German Energiewende is a "transition from below", started in the late 1970s (Maubach, 2013, p. 42), a time when the term "Energiewende" started to be used in the pro-renewables and anti-nuclear community (Krause, Bossel, \& Müller-Reissmann, 1980). The German government's decision to re-accelerate nuclear phase-out following the Fukushima disaster in 2011 and the definition of long-term goals up to 2050 in the 2010 Energy Concept and the 2011 Energiewende legislative package (BMWi, 2011; BMU, 2011) increased global attention for Germany's Energiewende. Rather than marking a radical change of path, these decisions build up on policies in place at least since the early 2000s (Renewable Energy Act adopted in 2000, building up on the Electricity Feed-in Act from 1990; nuclear phase-out decided in 2002), leading to a steady increase of the share of renewables in the German electricity mix to up to $27.3 \%$ in 2014 (Graichen, Kleiner, Litz, \& Podewils, 2015). The core policy instrument used to promote the uptake of renewables in Germany are technology-specific feed-in tariffs, although a recent reform of the German Renewable Energy Act fore- sees test runs for auctions of ground-mounted photovoltaic capacity from 2015 onwards (Bundestag, 2014). Today, $47 \%$ of installed renewables capacity in Germany is citizen-owned (Agentur für Erneuerbare Energien, 2014).

While its quantitative targets are clearly defined, the hierarchy of political objectives ${ }^{1}$ the Energiewende is to achieve remains subject to discussion (Joas, Pahle, \& Flachsland, 2014). One important objective and rationale for Germany's energy transition since its beginnings has been to gain followers on the way towards more renewables (Bundestag, 1988). Despite recent criticism concerning their economic efficiency, German feed-in tariffs and the resulting uptake of renewables contributed to a spectacular decrease in prices for renewable energy technologies worldwide, in particular for photovoltaics, making them more accessible to potential followers. The aim to promote renewables in partner countries also led to the establishment by Germany of various programs to encourage the uptake of renewables in other countries (Steinbacher \& Pahle, 2015). Morocco has been particularly targeted by these efforts (GIZ, 2012b), which makes it a relevant case to analyze the transfer of knowledge and ideas from the German energy transition and, in general, through transfer channels established with Germany.

Morocco's potential role as a multiplier for sustainable energy in developing countries, but also its market potential as the "most promising destination for solar and wind energy in the MENA region" (Vidican et al., 2013 , p. 2), and the prospect of importing "green" electricity from Morocco in the future, led Germany to invest considerable resources in technical and financial assistance in the field of renewable energy ( $\mathrm{KfW}$, 2014). Numerous programs, including policy advice, capacity-building measures, pilot projects and a bilateral energy partnership, have been established since the 1980s between Germany and Morocco, creating multiple channels of communication through which policy transfer can take place.

Although Morocco is not a major $\mathrm{CO} 2$ emitter on a global scale, a better understanding of its approach to renewable energy policy is of relevance: with its ambitious plans for renewable energy in the power sector, Morocco can aspire to a leadership role in Northern Africa and can serve as a source of inspiration and lessons for other African countries (Amrane, 2013). Its approach to energy transition governance can thus potentially provide lessons for other emerging and developing countries willing to avoid lock-ins in high-carbon energy systems in the future.

\footnotetext{
${ }^{1}$ At this occasion, it should be noted that "targets" such as the share of renewable energy were not considered "objectives" for the purpose of this paper. The aim was to explore what objectives should, in fine, be achieved via a higher share of renewables rather than considering such an increase as an objective in and of itself.
} 
Given these favorable basic conditions for transfer, the aim in this paper is to explore to what extent principles, policies or instruments in the field of renewable energy travelled through the channels of communication established between Germany and Morocco, given that the priorities the two countries pursue through the deployment of renewable energy differ in central respects. To carry out this analysis, the article follows a three-step approach: it sheds light on the policy objectives Morocco pursues with its "energy transition" (Section 4), provides examples of how lessons from the German energy transition and knowledge provided by German transfer agents were used in policy-making for renewable energy in Morocco (Section 5), and discusses what conditions made (selective) transfer possible between Germany and Morocco (Section 6). Prior to this, expectations from the policy transfer literature (Section 2) are summarized and methods presented (Section 3 ).

Analysis in this article is based on findings from forty-five semi-structured interviews, ranking exercises, as well as document analysis carried out in the framework of field research in Morocco in the first quarter of 2014. Results suggest that strong established transfer channels, Morocco's own claim to leadership, and Germany's reputation as a leader led experts and decision-makers to use evidence provided by German transfer agents despite differing objectives. However, while the diffusion of basic policy orientations ("more renewables") was effectively facilitated by German transfer agents, this was not the case for policy instruments, where negative lessons drawn from the German experience contributed to the choice of multicriteria tenders to promote renewables.

From a theoretical point of view, the case of renewable energy policy transfer to Morocco shows that differences in objectives do not preclude lessondrawing, but lead to selective transfer, hybridization (Evans, 2009, p. 246) or policy osmosis (Genovese, Kern, \& Martin, 2012). From the perspective of "leadership by diffusion" (Biedenkopf, 2012; Steinbacher \& Pahle, 2015), the transfer of knowledge on energy transitions requires followers' (potentially differing) political objectives to be taken into consideration. This finding adds to the discussion on the role of issuelinking and promoting co-benefits to facilitate the adoption of climate-friendly policies by countries with priorities other than climate protection (Cosbey, 2009).

\section{Policy Objectives as Potential Determinants for Transfer}

\subsection{Diffusion and Transfer of Sustainable Energy Policies}

The growing literature on policy transfer and diffusion ${ }^{2}$

${ }^{2}$ For an account of the terminology debate see for example has provided crucial insights into if and how models and policies spread across time and space. The spread of diverse environmental policy instruments (Holzinger, Knill, Heichel, \& Sommerer, 2010; Sommerer, 2011), energy policies (Matisoff \& Edwards, 2014; Stoutenborough \& Beverlin, 2008; Vasseur, 2014), including feed-in tariffs (Busch, 2003; REN21 Secretariat, 2012) and renewable energy portfolio standards (Chandler, 2009; Matisoff, 2008; Smithwood, 2011), is a strong indicator for interdependent policy-making in the field of environment and energy. Hypotheses have been formulated on why follower countries turn to foreign models in search for inspiration and lessons (e.g., Heinze, 2011), on what actors are involved in transferring policies (Marsh \& Sharman, 2009; Stone, 2004) and on how transfer is linked to policy success and failure (Dolowitz \& Marsh, 2000). From a geographical point of view, transfer and diffusion research has however been criticized for largely focusing on diffusion within or between OECD countries (Evans, 2004).

The potential "objects" of policy transfer under scrutiny in this paper are the rules and institutions governing the generation of electricity from renewable energy sources. Although this does not cover the entire scope of the German energy transition as a potential source of lessons, the focus can be justified taking into account the prominence of this sector both in the implementation of the Energiewende in Germany and in Moroccan-German cooperation over many years.

\subsection{Compatibility and Similarity of "Senders" and "Receivers" as Determinants for Transfer}

The compatibility or fit between a pioneering policy model and the regulatory tradition of potential follower countries has been identified as one of the main determinants for policy transfer (Busch \& Jörgens, 2005, p. 5; Heinze, 2011; Rose, 1991; Tews, 2002). The expectation is that the more a policy instrument, tool or idea is in line with existing institutions and administrative practices-and with domestic policy objectives-the more likely it will be adopted by a follower country. Beyond the requirement of regulatory fit, cultural and economic similarity between follower and leader country is also considered to influence which foreign models policy-makers and advisors take into account when formulating policies. By using "analytical shortcuts" in processes of bounded rational learning (Meseguer, 2005 , p. 2), only a limited number of foreign models (if any) are usually considered in the search for policy solutions. Besides the perceived success of the model and availability of information on a foreign model, the common belonging of follower and leader country to a

Holzinger, Jörgens and Knill (2007). The term policy transfer is employed in this paper since a specific, bilateral case of potential lesson-drawing is under scrutiny here. 
"cultural reference group" (Simmons \& Elkins, 2004, p. 175) makes it more likely for a follower to consider a specific foreign policy model. Looking at policies implemented in countries with similar cultural, religious, political, linguistic, or economic characteristics is expected to provide "highly relevant information on the appropriateness of a particular policy" (Simmons \& Elkins, 2004, p. 176), increasing the likelihood for transfer. With Morocco and Germany differing in many respects, this argument is put to a test in the analysis of policy transfer between them.

\subsection{Instrument Selection, Transfer and Policy Objectives}

Literature on policy transfer and diffusion regards the perceived "success" and "reputation" (Jänicke, 2005) of the pioneering model as important cognitive heuristics. These heuristics do however depend on policy objectives pursued and therefore on the indicators for success a follower country applies. Different elements of a foreign policy design can be perceived as successful, compatible and appropriate depending on what objectives the follower aims to achieve. An assessment of an energy policy's track record will therefore vary according to whether climate goals or low electricity prices, job creation or citizen participation or other objectives are prioritized. It therefore appears necessary to focus on the role of objectives for transfer outcomes and instrument selection in follower countries.

Choosing policy instruments is an inherently political process and reflects understandings and beliefs: "granted its [the government's] favorable attitude to doing something about it, which solution it wants to see in effect obviously depends on its beliefs how different measures will affect national interests and values" (Malnes, 1995, pp. 102-103). The policy field of renewable energy is no exception to the rule and the political economy of energy transition policies is receiving growing attention (Baker, Newell, \& Phillips, 2014; Mitchell, 2008). A range of instruments to promote renewable energies is available to policymakers, with different outcomes and effects on "national interests" to expect. Whereas feed-in tariffs provide security to smaller investors and can easily be designed to encourage decentralized energy generation, auctions are generally organized to bring about the most costefficient solution and are sometimes too complex and risky for households and small enterprises (see for example Jacobs et al., 2014; Kreycik, Couture, \& Karlynn, 2011 , p. 32). They can, however, be designed to promote other objectives beyond low prices, such as local economic development, as the case of South Africa shows (Eberhard, Kolker, \& Leigland, 2014). The choice of policy instruments-impacted or not by external impulses and knowledge about foreign models - thus appears as closely linked to the objectives an energy tran- sition should achieve in the eyes of decision-makers.

\section{Methods}

Findings and analysis in this paper rely on forty-five semi-structured interviews, forty of which included a ranking exercise, as well as on the analysis of documents including minutes of meetings, project reports, press releases and policy documents. Interviews were carried out in Rabat and Casablanca in February and March $2014^{3}$ with interview partners selected to cover organizations involved in energy-related projects of German-Moroccan cooperation (see Table 1). These projects were funded by different German departments (Ministry for Environment, Ministry for Economic Affairs, Ministry for Economic Cooperation and Development) and are implemented by GIZ, the German agency for international cooperation (Deutsche Gesellschaft für Internationale Zusammenarbeit) and/or KfW, the German development bank (Kreditanstalt für Wiederaufbau). Representatives of all main Moroccan institutions involved in the formulation and implementation of energy policies were covered, such as the Moroccan Ministry for Energy, Mining, Water and the Environment (Ministère de l'énergie, des mines, de l'eau et de l'environnement, MEMEE) and Morocco's vertically integrated, state-owned electricity and water utility ONEE (Office national de l'électricité et de l'eau). Within these organizations, the focus was put on highranking officials who had been in direct contact with German advisors, which does introduce a certain bias to the sample of interviewees. For an external view on Moroccan-German energy relations, representatives of international institutions (e.g., World Bank, African Development Bank) and third countries (Spain, France) were interviewed. Interviews lasted 65 minutes on average and were carried out in French or German, with quotes in this paper being translated by the author. Interviewees were guaranteed anonymity.

Table 1. Overview of institutions and organizations covered through interviews.

\begin{tabular}{|c|c|}
\hline ADEME & $\begin{array}{l}\text { French Environment and Energy } \\
\text { Management Agency }\end{array}$ \\
\hline ADEREE & $\begin{array}{l}\text { Moroccan Agency for the } \\
\text { Development of Renewable Energy } \\
\text { and Energy Efficiency }\end{array}$ \\
\hline AFD & French Development Agency \\
\hline AfDB & African Development Bank \\
\hline AHK & $\begin{array}{l}\text { German Chamber of Commerce in } \\
\text { Morocco }\end{array}$ \\
\hline Amisole & Moroccan solar industry association \\
\hline Cegelec & $\begin{array}{l}\text { French electrical engineering } \\
\text { company }\end{array}$ \\
\hline
\end{tabular}

3 Two interviews were carried out over the phone in Moroc$c o$, one interview was conducted in Germany. 


\begin{tabular}{ll}
\hline CFCIM & French Chamber of Commerce in \\
CNRST & Morocco \\
& Moroccan National Centre for \\
Consultants & Scientific and Technical Research \\
EIB & Energy policy consultants, Morocco \\
German & Embassy of the Federal Republic of \\
Embassy & Germany in Rabat \\
GIZ & German Development / \\
& International Cooperation Agency \\
IDE-E & Institute for Development, \\
& Environment and Energy in \\
IRESEN & Morocco \\
& Moroccan Institute for Research on \\
KfW & Solar and New Technologies \\
Maroc Sans & German Bank for Reconstruction \\
Nucléaire & Moroccan citizens' organization \\
MASEN & against nuclear energy \\
MEMEE & Moroccan Agency for Solar Energy \\
& Moroccan Ministry for Energy, \\
Mining, Water and the \\
Moroccan & Environment \\
Embassy & Morocco in Berlin \\
Saharawind & Sahara Wind Project: Energy for \\
SIE & Sustainable Development \\
Embanish & Moroccan Society for Energy \\
Investments \\
\hline & Siemens Morocco \& Tunisia \\
Economy and Trade section, \\
Spanish Embassy in Morocco \\
World Bank Morocco, Rabat office \\
\hline
\end{tabular}

\subsection{Ranking Exercise: Energy Transition Objectives}

To assess stakeholders' view on the objectives of Morocco's renewable energy policy, a ranking exercise modeled on the approach used by Joas, Pahle and Flachsland (2014) was carried out. Similar, yet often more complex forms of "card sorting" or "q-methods" have mainly been used in information architecture research, psychology and the social sciences (Müller \& Kals, 2004). Interview partners were asked to rank thirteen small paper cards in whatever form they judged most appropriate to answer the question "What are the objectives Morocco pursues through its new renewable energy strategy?". Interviewees were asked not to express what should be the objectives pursued, but what they thought to be the actual goals pursued through the planned increase of solar, hydro and wind capacity in Morocco. The objectives proposed were the following (original in French): energy independence, job creation, creating an industry, electricity exports, societal or identitary project, environmental and climate protection, decentralization, liberalization, avoiding nuclear energy, international community's expecta- tion, leadership, attracting investors, and affordable electricity prices. Interviewees were free to discard cards and ask for objectives to be added. The selection of objectives for the Moroccan case draws upon official statements such as a speech held by Morocco's Minister for Energy, Abdelkader Amara, on the objectives of Morocco's energy transition in Casablanca in November 2013 (Ministère de l'Energie, Mines de l'Eau et de I'Environnement, 2013a) ${ }^{4}$. Information gathered through interviews and the ranking exercise, was completed with official statements of Moroccan officials at major sectorial events ${ }^{5}$ and in document analysis.

\subsection{Analysis and Caveats}

Interviewees were free to rank several objectives at the same level of importance, which could have warranted a recalculation of ranks (for individual ranking results, see Table A1 in the Annex). For example, when three cards were ranked as top priorities, each of them could have been attributed $(1+2+3) / 3=2$ points as an average rank. The subsequent card, ranked as a 2 ndlevel priority by the respondent, would then have received rank 4 . The choice has been made in this paper not to use average ranks but to consider multiple cards ranked as top priorities as equally important as a single card ranked first in a strictly hierarchically ranking. Interviews were fully transcribed and coded around the 13 objectives proposed, in a qualitative content analysis approach (Gläser \& Laudel, 2010). Since the number of interviews and ranking exercises carried out is high in relation to the size of the Moroccan energy landscape, but too low for solid statistical inference, figures provided in the following sections need to be considered within the context of the interviews and taking into account the variety of forms-strictly hierarchically or not-in which cards were ranked by interview partners.

\section{Goals and Practice of the Moroccan "Energy Transition"}

\subsection{Morocco's Energy Challenges}

Morocco's energy system faces numerous challenges, putting it in a "very precarious energy and financial situation" (Vidican et al., 2013, p. 9) and pushing it to look for ways to increase capacity in recent years. First of all, given the country's minimal domestic fossil fuel

\footnotetext{
4 "Refusal of nuclear power" was added as an objective to explore similarities with the German approach to energy transition governance.

${ }^{5}$ CGEM Conference on energy transition, 27 November 2013, Casablanca; Solemn plenary session of the Académie Hassan II des Sciences et Techniques, 19 and 20 February 2014, Rabat; Solaire Expo, 26 February 2014, Casablanca; 8th GermanAfrican energy forum, G, 14 and 15 April 2014, Hamburg.
} 
resources, Morocco is heavily dependent on imports; secondly, Morocco's economic and demographic growth caused a steep increase in total energy demand; thirdly, demand is also rising on a per capita basis as standards of living rise. As a consequence, primary energy supply rose by almost $60 \%$ between 2002 and 2012. According to a recent comprehensive assessment of the Moroccan energy sector by the International Energy Agency, oil provides two thirds of Morocco's primary energy consumption in 2012, followed by coal $(16 \%)$, biofuels $(7.4 \%)$, natural gas $(5.7 \%)$, net electricity imports $(2.2 \%)$, hydro $(0.7 \%)$ and wind (0.3\%) (IEA, 2014, p. 11). While per capita energy consumption nearly doubled between 2002 and 2011, import dependence remained relatively stable at extremely high levels comprised between 93.0\% (2010) and $97.5 \%$ (2008). The financial burden of net energy imports was multiplied by more than four during that time (Direction de l'Observation et de la Programmation, n.d.). Although total electricity generation in Morocco increased by almost 80\% from 2002 to 2012, average electricity consumption is still eleven times lower than the IEA average. However, Morocco's strong reliance on fossil fuels leads to a C02-intensity per unit of GDP higher than the average of member countries of the International Energy Agency (IEA, 2014). Morocco's internationally praised rural electrification program (Programme d'électrification rurale globale, PERG) increased the share of electrified households from $18 \%$ in 1995 to over $98 \%$ today.

\subsection{A New Energy Strategy}

Morocco's ambitious renewable energy targets are at the core of its "new national energy strategy" (Ministère de l'Energie, Mines de l'Eau et de l'Environnement, $2013 b)$ defined in 2009. The strategy also foresees an increase of conventional capacity, but introduces significant solar and wind capacity for the first time. Morocco's renewable energy and energy efficiency targets are ambitious, with the share of renewable energy in total primary energy consumption set to increase from $5 \%$ in 2009 to $20 \%$ in 2030 . Forty-two percent of installed electricity capacity should be renewable by 2020 (Ministère de l'Energie, Mines de l'Eau et de l'Environnement, $2013 \mathrm{~b}, \mathrm{p} .33$ ) and $15 \%$ energy savings are aimed for by 2030 (Ministère de l'Energie, Mines de l'Eau et de l'Environnement, 2013b, p. 26) compared to a business-as-usual scenario. Among renewables, only hydro (1700 MW, with only about $10 \%$ contribution to electricity generation due to a lack of precipitation in recent years) and wind (750 MW, of which $300 \mathrm{MW}$ came online in early 2015) have significant capacity installed today, with total electricity generation capacity amounting to about $7800 \mathrm{MW}$, including recent additions of the Tarfaya wind park and additional units at the Jorf Lasfar coal plant. Despite the recent adoption in 2014 of a roadmap for solar photovoltaics, announcing the effective opening of the mid- and low-voltage levels to generators, a regulatory framework for this type of small-scale installations is still missing.

The two main legal texts for the implementation of Morocco's renewable energy strategy are law 13-09 on renewable energies, granting the possibility to private investors to develop renewable energy projects, and law 47-09 on energy efficiency. Even more central to the Moroccan energy strategy are the two national plans King Mohammed VI launched in 2009 and 2010 respectively, the Moroccan Solar Plan and the Moroccan Integrated Program for Wind Energy with a targeted total capacity of 2000MW solar and 2000MW wind by 2020 (MASEN, 2010; ONE, 2010). A 2000MW goal for hydro-electricity was fixed as well, but is almost reached already through existing installations and plants under construction (Ministère de l'Energie, Mines de l'Eau et de l'Environnement, 2013b).

To implement the Moroccan solar plan, power purchasing agreements (PPAs) are awarded through tenders at predefined sites (PWMSP Project Consortium, 2013, p. 15). In the first phase of the Moroccan solar plan, tenders for what is to become the world's largest concentrated solar power (CSP) complex at Ouarzazate were launched in two phases in 2012 and 2015. The first plant, Noor 1, is expected to become fully operational in 2015. The integrated wind plan relies on buildown-operate-transfer contracts (ONE, 2014), with $850 \mathrm{MW}$ of wind capacity still to be awarded.

\subsection{Is Morocco Pursuing an Energy Transition?}

Despite these ambitious objectives for renewables, the question of whether Morocco is pursuing an energy "transition" was raised by several interview partners. German and other international officials in Morocco were generally skeptical about speaking of a "transition" in the Moroccan case and tended to see developments primarily as an "enlargement of the electricity mix" while, in Germany, "you can speak of a 'real' transition" 6 . One German official underlined the concept of an energy transition had only been used in the past year or so by Moroccan officials and suggested it was a "trendy" concept, similar to other "concepts that are en vogue like sustainable development, green economy, circular economy and the like" ${ }^{\prime 7}$. Some Moroccan officials shared this view, noting that "in Morocco, one has to speak of an energy-development rather than an energy transition. I do not see this as a 'Wende' [sic], a U-turn, but as a new strategic orientation with a focus on renewable energy and clean technologies (...)" ${ }^{\prime 8}$. For

\footnotetext{
${ }^{6}$ International interview partner, private sector, 21/02/2014, Casablanca.

${ }^{7}$ German interivew partner, GIZ, 27/02/2014, Rabat.

8 Moroccan interivew partner, IRESEN, 04/03/2014, Rabat.
} 
several interview partners, given the change of path outlined in Morocco's current national energy strategy, from a system almost entirely based on the import of fossil fuels towards considerable shares of renewable electricity capacity, the use of the concept of energy transition to the Moroccan case appeared justified, underlining that in Morocco, "the energy transition is not a choice, it's a necessity" ${ }^{\prime}$. This is in line with public statements by high-ranking officials including Minister Amara: "We made the energy transition a clear, strategic political choice dictated by the clear-sighted and determined vision of His Majesty the King Mohamed VI (...)" (Ministère de l'Energie, Mines de l'Eau et de l'Environnement, 2013a, p. 2).

\subsection{Stakeholders' Views on the Political Objectives of Morocco's Renewable Energy Strategy}

Clear trends regarding priority objectives of the Moroccan energy transition towards more renewables could be identified throughout the interviews and rankings. The objective seen as the top priority was (increasing) "energy independence" with an average rank of 1.9, putting it above "job creation", which comes second with an average rank of 3.1. "Avoiding nuclear power" (8.0) and "decentralization" (7.4) were considered to be the goals the Moroccan government is pursuing the least intensely with its renewable energy strategy ${ }^{10}$.

\subsubsection{Increasing Energy Independence-The $\mathrm{N}^{\circ} 1$ Focus of Morocco's Energy Transition}

According to those interviewed, reducing dependence from energy imports is the top priority the Moroccan government is pursuing with its renewable energy policy. German and international interview partners in Morocco saw this objective as being even more important (both 1.6), on average, than Moroccan interview partners (2.1). The goal of energy independence is not entirely self-explanatory: electricity imports from Spain tend to be cheaper than electricity produced within Morocco (Agueniou, 2013). Nevertheless, economic motives were mentioned ("we could save a lot of money if we become independent. I'd call it a 'key success factor $\left.{ }^{\prime \prime 11}\right)$. Political drivers for energy independence did however prevail in the interviews, with increased independence most often described as a strategic goal ${ }^{12}$ and renewables being a way to use "national resources" rather than foreign ones. Although there was agreement among interview partners on the importance of this goal as a driver for renewable energy deployment, several

\footnotetext{
${ }^{9}$ Moroccan interivew partner, MEMEE, 11/03/2014, Rabat.

${ }^{10}$ Cards excluded by interviewees were not considered in the calculation of this average rank.

11 Moroccan interview partner, SIE, 06/03/2014, Rabat.

12 Moroccan interview partner, consultant, 10/03/2014, Rabat.
}

recognised that Morocco is unlikely to achieve full independence from imports: "[...] it's an objective, but one that will never be reached, it's impossible"13.

\subsubsection{The Socio-Economic Cluster: Job Creation and Industrial Policy}

Many interviewees chose to thematically cluster objectives they saw as being linked. This was most often the case for socio-economic goals, the second most important group of objectives of Moroccan energy policy, in the eyes of respondents. Job creation (average rank 3.1), affordable electricity prices (4.0), the development of renewable energy industries (4.1) and attracting investors (4.3) were commonly described by interviewees as causing each other: "creating jobs is a consequence of attracting investors"14. The linkages between renewable energy projects and socioeconomic benefits were commonly referred to as an "integrated approach" by interview partners and in strategic documents, showing Morocco's ambition to achieve a higher degree of energy independence and socio-economic objectives simultaneously (ONEE, 2014).

Among socio-economic objectives, job creation was perceived as the most important goal pursued by the Moroccan government through its energy strategy. German officials ranked it even higher (2.2) than Moroccan (3.2) and international officials (4.1). At the same time, German and third country respondents frequently expressed doubts about the appropriateness of current policy measures to reach this goal, despite the inclusion of local content thresholds in the tender requirements for renewable energy projects. Morocco's focus on few large-scale renewable energy projects, considered less likely to create a high number of jobs, rather than a decentralized approach led several interview partners to put into question the alignment between policy objectives and instruments: “(...) it's always the same thing, also with the objective of creating jobs: there is ambition but the necessary means are not put in place ${ }^{\prime 15}$. The sincerity of the goal of job creation itself was also questioned, concluding that "those job creation arguments are only façade" ${ }^{16}$. Some suggested the goal of creating jobs was in any case only to be achieved indirectly, by providing reliable electricity at long-term competitive prices to the industry ${ }^{17}$.

\subsubsection{Decentralization and Societal Project}

\section{Decentralizing electricity generation was either refused}

\footnotetext{
13 Moroccan interview partner, ADEREE, 10/03/2014, Rabat.

${ }_{14}$ Moroccan interview partner, SIE, 06/03/2014, Rabat.

15 International interview partner, private sector, 21/02/2014, Casablanca.

${ }^{16}$ German interview partner, GIZ, 12/02/2014, Rabat.

${ }^{17}$ Moroccan interview partner, consultant, 08/03/2014, Skype.
} 
as a goal by interviewees or understood by several Moroccan interview partners as the distribution of a small number of large plants over the whole territory. As one interviewee put it “(...) rooftop PV is not a good thing, the stability of grids is our highest good. (...) Just compare it with growing crop: people do not grow their own crop on their rooftops either! Society always transforms things into centrally processed mass products, it's just more efficient" ${ }^{18}$. Only a small number of interview partners saw decentralization or democratization as one of the objectives currently pursued. One of the officials directly involved in the on-going process of opening electricity production to households and small enterprises argued "we are about to do a 'democratization' of photovoltaics. All categories of consumers must be able to contribute to the national energy [transition] process" ${ }^{19}$.

Despite the low perceived importance of decentralization, the Moroccan energy transition was nevertheless considered a "societal or identitary project" by a considerable number of Moroccan officials. One interview partner, who ranked decentralization as the least important goal, underlined in the same conversation that the "energy transition [is] a societal project, carried by the Moroccan society and done by the Moroccan society"20, hinting to a different understanding of societal participation in an energy transition as would be the case for the German Energiewende. This might partly be explained by the fact that a "societal or identitary project" also included an important element of territorial integrity in the eyes of several Moroccan officials. The distribution of large-scale plants across Morocco (which is, as stated above, understood by some as "decentralization") includes the "Southern provinces", the disputed territory of the Western Sahara. As Minister Amara put it in a public speech "this [renewable energy] program encompasses also the national grid in our Southern provinces in the framework of a long-term vision of electricity interconnection with the Sub-Saharan countries via Mauritania and Senegal" (Ministère de I'Energie, Mines de l'Eau et de l'Environnement, 2013a, p. 7).

\subsubsection{Climate Protection}

Climate protection as a perceived goal of Morocco's energy transition received a medium average rank (4.9), but respondents generally described it as an automatic consequence of the energy policy Morocco was putting in place rather than a driver for the deployment of renewables. Major differences between Morocco and Germany were pointed out on this issue: "Germany develops renewables because of its [climate] obligations on the European side. For Morocco,

\footnotetext{
${ }^{18}$ Moroccan interview partner, academia, 07/02/2014, Rabat. ${ }^{19}$ Moroccan interview partner, civil society, 19/02/2014, Rabat. ${ }^{20}$ Moroccan interview partner, ADEREE, 24/02/2014, Rabat.
}

climate protection is rather a consequence than an objective"21. Although public statements position Morocco as an "actor of the European energy transition" in support of Europe's climate protection goals (Ministère de l'Energie, Mines de l'Eau et de l'Environnement, 2013a, p. 8), interviewees on the ground were somewhat more reluctant to see a true commitment towards climate protection, beyond the country's readiness to export green electricity to Europe ${ }^{22}$. Climate protection was also commonly linked to the objective of responding to the "expectations of the international community". One German official called environmental and climate issues "sales arguments" 23 , whereas one international actor critically noted that "climate protection and 'expectations of the international community' go together. Developing countries are always asked to do something against climate change the others caused" ${ }^{\prime 2}$. In sum, although interview partners implicitly or explicitly saw the need for global action against climate change, Morocco's renewable energy programs were by most not considered as being driven by this objective.

\subsubsection{Avoiding Nuclear Energy}

One of the most clear-cut differences between Moroccan and German energy transition objectives is the role nuclear energy and, to a lesser extent, fossil fuels play therein. Whereas for Germany, a full phase-out of nuclear power by 2022 has been decided and confirmed (BMWi, 2011), not a single Moroccan interview partner could exclude the nuclear option for Morocco in the middle or long run, although many of them expressed their hope that Morocco would be able to refrain from using nuclear power. With an average rank of 8.0, "avoiding nuclear energy" is the goal interviewees did perceive as being the least pursued by current Moroccan energy policy. About half of Moroccan interview partners $(48 \%)$ completely excluded it as a potential objective of Morocco's energy strategy, more than for any other card. In its 2009 climate action plan, Morocco still foresaw the installation of $2 \times 1000 \mathrm{MW}$ of nuclear power between 2020 and 2030 (Département de l'Environnement, 2009, p. 14), but no nuclear plans are officially pursued at the moment. Several interview partners suggested the French government aimed at promoting nuclear energy in Morocco and a bilateral agreement to cooperate on this issue was unanimously adopted by the Moroccan parliament in 2014 (MAP,

\footnotetext{
${ }^{21}$ Moroccan interview partner, consultant, 08/03/2014, Skype. 22 Spain's refusal to sign a declaration of intent regarding the Mediterranean Solar Plan in 2012 currently precludes electricity exports from Morocco and the development of renewable energy projects for export purposes, at least in the medium term.

${ }^{23}$ German interview partner, GIZ, 25/02/2014, Rabat

${ }^{24}$ International interview partner, private sector, 07/03/2014, Casablanca.
} 
2014). As one interview partner summarized it, the predominant view among stakeholders on this issue was that "Moroccan civil society is probably firmly opposing nuclear power (...) But, in reality, can we afford to refuse anything?" 25 .

\subsection{Differences in Policy Objectives between Germany and Morocco}

Morocco's and Germany's energy transitions share common features, such as an aim to reduce dependence on imports of fossil fuel. However, three of the core realities or aims of the German renewable energy policiesdecentralization, climate protection and establishing an alternative to nuclear energy-do not appear as goals of the Moroccan energy transition. Whereas the role of climate protection as a driving force for renewables in Morocco is ambiguous, establishing an alternative to (potential future) nuclear power and decentralizing electricity generation were considered the least important goals of Moroccan renewable energy policy according to those interviewed. In summary, an analysis of rankings, interviews and Morocco's policy framework shows that the Moroccan energy transition is one where decisions are taken "always top-down"26, and which is oriented towards the major objectives of mitigating energy import dependence (resulting in openness towards all sources of energy, including unconventional oil and gas, and nuclear), as well as job creation and industrial policy.

Although independence and socio-economic objectives do certainly also play a role for the German Energiewende, differences in priorities between the German and the Moroccan energy transition strategies exist. While these differences are far from being unexpected given the countries' differing economic, political and geographic situation, the transferability of lessons from the German Energiewende in the presence of differing priorities requires close scrutiny.

\section{Renewable Energy Policy Transfer between Germany and Morocco}

The full range of transfers of ideas related to cooperation between Germany and Morocco and to active policy promotion by Germany cannot be reported within the limits of this paper. Three important areas will be used to illustrate how ideas travelled either from the German Energiewende example or through transfer channels with Germany: the place of renewables in the Moroccan energy strategy and the choice of CSP (5.3), the issue of decentralized electricity generation (5.4), and the refusal of feed-in tariffs (5.5). Prior to this, transfer channels will be reviewed (5.1) and the desira-

${ }^{25}$ Moroccan interview partner, consultant 08/03/2014, Skype.

${ }^{26}$ Moroccan interview partner, consultant 08/03/2014, Skype. bility of transfer from Germany in the eyes of Moroccan stakeholders will be discussed (5.2).

\subsection{A Fertile Ground for Transfer}

Cooperation between Morocco and Germany in the field of renewable energy has been effective since the 1980s. A "special energy program" (Osianowski, 1997) paved the way for the introduction of first renewable energy demonstration projects in Morocco and supported the country in its efforts to increase the electrification rate from $18 \%$ in 1995 to nearly $100 \%$ today. In the following years, the identification of renewable energy and especially wind potential within the special energy and the TERNA (Technical Expertise for Renewable Energy Application) program (Altmann, 2012; GTZ, 2009), prepared the ground for further policy developments. The crucial role of these early projects in preparing the ground for future renewable energy developments and in granting German advisors an exceptional role was confirmed by Moroccan and German interview partners involved in bilateral cooperation with Morocco since the time of the special energy program $^{27}$. To increase the visibility of German support in this field, the decision was taken upon the demand of Germany to replace "environment" with "(renewable) energy" as one of three as one of three official focus areas of bilateral cooperation from 2014 onwards ${ }^{28}$.

As the first of the MENA (Middle East and North Africa) countries, Morocco entered into a bilateral energy partnership with Germany, in July 2012 (BMWi, 2012). With more than $€ 850$ Mio. of loans and grants, Germany also provided the biggest share of financing for the first two phases of the Ouarzazate concentrated solar power (CSP) project (KfW, 2014). In June 2013, Morocco's commitment to developing sustainable sources of energy and its strong ties to Germany earned it a membership in the now inactive "Club of Energiewende Countries" (Club der Energiewendestaaten) or Renewables Club (BMU, 2013).

The strong presence of German transfer agents and their proximity to Moroccan decision-makers was seen as being directly linked to Germany's own energy transition experience: “(...) Germany is really focusing its efforts in the energy sector in Morocco. They are very strong when it comes to renewable energy and efficiency, it's therefore a law of nature that they are the most active here" ${ }^{29}$. In particular, the role of GIZ, Germany's agency for development and international cooperation, was considered crucial: "GIZ is a battle force ${ }^{\prime 30}$. This is linked to the unique position of GIZ's

\footnotetext{
27 Moroccan and German interview partners, MEMEE and GIZ, 11/03/2014 and 27/02/2014, Rabat.

${ }^{28}$ German interview partner, 12/02/2014, Rabat.

29 International interview partner, France, 04/03/2014, Rabat

30 International interview partner, France, 04/03/2014, Rabat.
} 
advisors, some of whom are operating from offices within the Moroccan Ministry for Energy, with direct communication channels to decision-makers.

\subsection{Perceived Desirability of Drawing Lessons from the German Energiewende}

A central point for the discussion of transfer between Germany and Morocco is an assessment of Moroccan officials' views on the Energiewende and of the transferability of experiences from Germany to the Moroccan context. Interviewees on the Moroccan side were univocal when it came to considering the German energy transition experience as an outstanding model and an inspiration: "I, personally know that there is nothing and no one better than Germany, also when you look at technology" 31 , "Germany is the (...) world leader in renewable energy, so it's a very good thing to observe what they do and to have them tell us what works and what does not work" 32 or "Morocco is definitely following Germany on its way" ${ }^{33}$ are just some out of a large number of, often unsolicited, statements on German leadership in renewable energy.

Some Moroccan interview partners however underlined differences with regard to the driving forces behind their country's energy transition. The German Energiewende was referred to as a "choice", as a "determined, ambitious, courageous" 34 policy or even as a "luxury decision", since "in Europe you can exit nuclear power just like that and replace it by anything you want" ${ }^{\prime 35}$. The Moroccan energy transition, in contrast, was seen as a response to an urgency, namely rising fossil fuel prices, especially in $2007 / 2008^{36}$. Some Moroccan interview partners also put the decision in the context of a global trend: "It's a necessity. We don't have a choice. Like all other countries in the world we want to appropriate new, clean technologies"37.

\subsection{The Role of Transfer in the Development of the Moroccan Energy Strategy and Solar Plan}

Interview partners who were involved in the design of the 2008 Moroccan energy strategy and the 2009 Moroccan solar plan agreed that a study (Roller et al., 2007) prepared by German research institutes, financed by German development cooperation and initiated by Moroccan and German actors ${ }^{38}$ had a "very, very important influence" ${ }^{39}$. King Mohammed VI and

\footnotetext{
${ }^{31}$ Moroccan interview partner, ADEREE, 10/03/2014, Rabat.

32 Moroccan interview partner, ADEREE, 06/03/2014, Rabat.

33 Moroccan interview partner, ADEREE, 24/02, 2014, Rabat.

${ }^{34}$ Moroccan interview partner, ADEREE, 24/02/2014, Rabat.

35 Moroccan interview partner, consultant, 10/03/2014.

${ }^{36}$ Moroccan interview partner, MEMEE, 11/03/2014, Rabat.

${ }^{37}$ Moroccan interview partner, ADEREE, 10/03/2014, Rabat.

38 Moroccan interview partner, MEMEE, 11/03/2014, Rabat.

39 Moroccan interview partner, MEMEE , 12/03, Rabat.
}

the Moroccan government had come under considerable pressure to develop a new energy strategy due to sharply rising fossil fuel prices in 2007 and 2008. The German-sponsored study (Roller et al., 2007) outlined four possible future energy scenarios, shedding a particularly positive light on a scenario entitled "balanced portfolio", with a high amount of CSP and wind. Necessary adaptations to the legal and institutional framework were described in detail and Morocco's tremendous renewable energy potential underlined.

By demonstrating an attractive cost-benefit ratio of renewable energy for Morocco, by providing estimates of expected job creation, and by referring to CSP as a potential area for industrial development, the study provided arguments to proponents of renewable energy, strengthening their bargaining position. The study was presented to the Minister for Energy by the German consultants and representatives of ADEREE made sure it was subsequently transmitted to the royal cabinet, where it was "read with great interest", "outplaying another study" 40 carried out at that time by a major international consultancy firm, which recommended to focus on coal. The decision to introduce ambitious renewable energy targets to the Moroccan energy strategy and the subsequent choice of CSP for lighthouse projects in the Moroccan solar plan is of course not solely due to the effect of evidence provided by German experts. However, interview partners directly involved in the process, agreed on the decisive role of the detailed scenarios the study provided, reinforcing the position of pro-renewables voices within the Moroccan energy landscape (ADEREE, MEMEE) and facilitating decision-making in favor of ambitious renewables targets. Apart from cognitive resources, the availability of preferential funding for renewable energy projects from the German KfW, the World Bank and other financial institutions might also have played a role in shifting the focus to renewables. However, interview partners did not see the availability of funding for these projects as the decisive driving factor for the general decision to introduce renewables.

As far as technology choice is concerned, transfer of knowledge and evidence through German-Moroccan channels, together with financial incentives through preferential loans made available by $\mathrm{KfW}$, the World Bank's Clean Technology Fund and others, undoubtedly facilitated the decision to focus on CSP in the first phase of the Moroccan Solar Plan. On a micro-level, Germany funded the attendance of a high-ranking official from MEMEE to a CSP conference in Germany only weeks before the surprising announcement of the Moroccan Solar Plan and of its focus on CSP. The official's enthusiastic report back at MEMEE on the opportunities of CSP he had been able to discover at the conference provided another impulse in favor of the Moroc-

${ }^{40}$ Moroccan interview partner, MEMEE, 11/03/2014, Rabat. 
can Solar Plan and of choosing CSP for its first stages of implementation. Germany's role in technology choice was recognized and seen critically by a number of interview partners, in particular by officials from third countries: "The German policy was to say that they had already done photovoltaics in Germany, so they would now invest in CSP. CSP, you can't do it in Germany, so let's do it in Morocco. That is the reason Morocco went for the most expensive technology $(. . .)^{41 \prime}$. The cost of electricity generated at CSP plants was seen as particularly problematic in the absence of concrete prospects of exporting electricity to Europe. Several interview partners therefore expressed their expectation for Germany to continue its support to electricity export projects despite resistance from other EU member states.

\subsection{Keeping Decentralization on the Political Agenda}

Well before the announcement of Morocco's energy strategy, German advisors were closely involved in the development of a draft law for renewable energy that was adopted in the Council of Government, leading media to announce that Morocco "imported the [German] Renewable Energy Act" (Klimaretter, 2007). Although the law was not adopted by parliament due to upcoming elections, it successfully brought the issue of decentralized, small-scale renewable electricity generation to the agenda. Building up on this foundation, representatives of $\mathrm{GIZ}$-together with (private sector) actors from Morocco-subsequently supported an opening of the low-voltage level to private producers of renewable electricity within the framework of the subsequent renewable energy law $n^{\circ} 13-09^{42}$. Studies (Sidki, 2011; Jäger, 2011) were carried out on the initiative of GIZ to show the potential of residential photovoltaics in Morocco with the deliberate aim of keeping discussions ongoing and supporting those in favour of decentralization among Moroccan decision-makers. A high-level official within the Moroccan Ministry for Energy recalled GIZ "demonstrated many times that we could develop 2000MW (...) through residential [PV] only. The Germans said and repeated that, I can confirm" ${ }^{\prime 4}$, leading to the topic regaining momentum in the political debate in 2013 and 2014. A Moroccan consultant involved in working groups with $\mathrm{GIZ}$ and MEMEE representatives described GIZ's role as "informing the debate and bringing all relevant stakeholders to the table", "getting the Ministry to think" and "showing (...) that everyone could win from an opening of the low voltage level". Germany's involvement, according to the consultant, was crucial in "getting things moving again", "from a categorical 'no' to

${ }^{41}$ International interview partner, Spain, 27/02/2014, Rabat.

${ }^{42}$ German interview partner, GIZ, and Moroccan interview partner, consultant, 25/02/2014 and 10/03/2014, Rabat.

${ }^{43}$ Moroccan interview partner, MEMEE, 13/03/2014, Rabat. the possibility to discuss the issue" ${ }^{\prime 4}$.

According to a range of observers, an informal alliance of GIZ officials convinced of the importance of small-scale renewables based on the German Energiewende experience and of Moroccan private sector representatives managed to keep the issue of decentralised generation on the agenda. Regular workshops and meetings with MEMEE officials led the topic to be picked up again by the government and, in 2014, a roadmap for photovoltaics including the low voltage level was eventually presented. Policy transfer in this instance thus affected the stage of agenda-setting in the decision-making process.

\subsection{Negative Lesson-Drawing Regarding Policy Instruments}

While the abovementioned influential Germansponsored study (Roller et al., 2007) also recommended to consider feed-in tariffs as a policy instrument and German advisors had tried to promote this instrument in Morocco at the time of the first attempt for a renewable energy law, the ministerial reaction to this idea was negative (Jäger, 2011). Moroccan interview partners considered feed-in tariffs inappropriate for the Moroccan context, in particular because of what they perceived as negative lessons from Germany and other European countries: "the example of feed-in tariffs that would rather be a negative lesson. They had a massive exit of cash flow" ${ }^{\prime 4}$. Although negative lessondrawing from the German experience was an important reason for officials' refusal of feed-in tariffs, it was not the only one.

Even more important was the view that feed-in tariffs did not fit the policy objectives Morocco pursued. Most Moroccan interviewees who expressed their opinion on this issue did not see any potential benefit of following Germany's example of feed-in tariffs, which were expected to increase electricity prices without providing benefits in terms of industrial policy, contrary to their effect in Germany: "In final, feed-in tariffs benefit the industry. As we don't have any renewable energy technology industry in Morocco (...) they are not interesting for us at all. Although their effect in terms of massive RES deployment, GDP, job creation, added valued and wealth creation [in Germany] is really important ${ }^{\prime \prime 6}$. This position was not only common among interview partners from MEMEE and ONE, but also shared by academics: "In Germany, the feed-in tariff incentivized people (...). Here, it is not possible. We cannot do a feed-in tariff, this policy cannot work in Morocco. There is no alternative to first developing large-scale projects to render the technology profitable

\footnotetext{
${ }^{44}$ Moroccan interview partner, consultant, 10/03/2014, Rabat.

${ }^{45}$ Moroccan interview partner, ADEREE, 06/03/2014, Rabat.

${ }^{46}$ Moroccan interview partner, ADEREE, 24/02, 2014, Rabat.
} 
and when it is profitable, the population can get involved. But you cannot do it exactly like Germany" 47 .

Some German officials went as far as to draw parallels between the refusal of feed-in tariffs and general skepticism towards decentralized electricity generation due to French colonial heritage ("this focus on large projects is a sort of French heritage in Moroccans' hearts and minds-that's a pity, but not very surprising" ${ }^{48}$ ). A second central reason for resistance against feed-in tariffs mentioned was their potential impact on local electricity distribution companies ("régies"), who would see their revenues decrease if self-generation increases. A third explanation given by a small number of interview partners for the refusal of feed-in tariffs in Morocco was that World Bank officials had allegedly expressed a strong preference for an auction system for renewables instead of feed-in tariffs in Morocco. Given the high amounts of funding made available by the World Bank for renewable energy projects, this preference could have had an additional influence on policy makers' decisions. Most importantly however, this element of the German energy transition approach was considered inappropriate given the regulatory culture, economic and social framework conditions and policy objectives pursued through renewables in Morocco.

\subsection{Summary of Transfer Outcomes}

Although, in a complex decision-making process, the exact "share" of any source of inspiration cannot be quantified, findings from interviews leave little doubt about the importance of interaction with German officials for advocates of renewable energy in Morocco. Germany has a unique position in the field of renewable energy in Morocco as compared to other bilateral partners and even multilateral institutions. For those interviewed, the German energy transition was the main point of reference in the field of renewable energy policy, from which lessons (positive and negative ones) could be drawn.

This section's aim was to provide examples on the transfer of know-how, evidence and experience from German transfer agents and/or the German Energiewende to Morocco, with a focus on the outcome of these transfer processes. In summary, German efforts to promote renewables were effective in empowering pro-renewables advocates and in providing crucial evidence facilitating the reliance on renewables in the Moroccan energy strategy. Evidence provided very likely also contributed to the decision to start the implementation of the Moroccan solar plan with a largescale CSP project, along other factors such as available funding. Ongoing advocacy for decentralized electricity generation by German advisors, through workshops,

\footnotetext{
${ }^{47}$ Moroccan interview partner, academia, 25/02/2014, Rabat. ${ }^{48}$ German interview partner, GIZ, 12/02/2014, Rabat.
}

studies and working groups, contributed to bringing the issue of small photovoltaics to the agenda and keeping it there until the recent announcement of a roadmap for photovoltaics including small-scale generation. Despite earlier attempts to promote Germanstyle feed-in tariffs in Morocco, negative lessons drawn from the German Energiewende experience concerning this instrument contributed to the selection of an alternative policy instrument.

Despite priorities being perceived as different, the (selective) transfer of principles and ideas provided by German advisors or from the German Energiewende, was possible in Morocco. This finding is discussed in the next section.

\section{Discussion: Explaining Lesson-Drawing when Objectives Differ}

Indications of effective policy transfer and lessondrawing between Germany and Morocco only partly confirm expectations from the policy transfer literature on the need for policy objectives to be similar for a sender's model to be taken into consideration (see Section 2.2). To explain when policy transfer is possible despite differing approaches to energy transition governance, the following elements can be considered.

If similarity is seen as a determinant for transfer, Germany is not a "most likely" source of lessons for a Moroccan energy transition. Moroccans interviewed did nevertheless see few alternatives to considering the German model of energy policy, because it was perceived as "leading". Morocco aims for-at leastregional leadership in the field of renewable energy, possibly stretching out to the whole of Western Africa ("Morocco can become a reference" ${ }^{49}$ ). One interview partner summarized the Moroccan aim of belonging to the same group of leaders as Germany as follows: "What you hear right now in Morocco is they 'want to do it just like Germany' and there is no reason not to do as well as the Germans do, especially because Morocco has sunshine in addition! They observe very closely what is happening in Germany and want to do that too"50. Thus, the aim of belonging to a common "reference group" (Elkins \& Simmons, 2005, p. 43) of leaders in renewable energy, might explain Morocco's willingness to "follow Germany on its way" 51 . The perceived success and reputation of the German model did, in the case of Morocco, allow for consideration of the German Energiewende as a legitimate source of lessons despite clear differences with regard to objectives pursued. This was decisively facilitated by struc-

\footnotetext{
${ }^{49}$ Moroccan interview partner, consultant, 10/03/2014, Rabat.

50 International interview partner, private sector, 21/02/2014, Casablanca.

51 International interview partner, private sector, 21/02/2014, Casablanca.
} 
tures of bilateral cooperation (presence of German advisors, capacity-building measures, study tours, workshops etc.) in place since the 1980s. These channels not only allow for learning but also increase the "availability" of the German model-a central condition for policy transfer (Elkins \& Simmons, 2005, p. 44).

It can be underlined at this point that "moral support", "a vision, a philosophy", "knowledge about longterm scenarios", "Energiewende soft skills" 52 and "knowledge about technologies and system management" were very frequently cited as items Moroccans hoped to transfer from Germany to support their own energy transition, regardless of differences in what is to be achieved through the deployment of renewables.

From a theoretical point of view, the case of renewable energy policy transfer between Germany and Morocco shows that the reality of policy transfer needs to be assessed along different policy dimensions (Klingler-Vidra, 2014, p. 58). Analysis presented in this article shows that the study of policy transfer cannot be limited to assessing whether a specific policy was adopted elsewhere, but needs to take into account that even if differing policy objectives and regulatory traditions prevent instruments from traveling across borders, transfer is possible and can impact fundamental policy orientations.

\section{Conclusion}

Literature on policy transfer, instrument selection and leadership points to the importance of similar policy objectives for transfer to happen. Findings presented in this article do however call for a more nuanced approach to the assessment of policy transfer.

From the analysis of ranking exercises and semistructured interviews presented in this article, energy independence and socio-economic objectives emerge as the central drivers for Morocco's renewable energy strategy in the eyes of those interviewed. With decentralization, climate protection and avoiding nuclear power not being considered (important) objectives in Morocco, significant differences compared to policy objectives and realities of the German Energiewende are visible.

Despite these differences, a shared aim for leadership, a longstanding history of cooperation in the energy sector and Germany's strong reputation as a leader in renewable energy created opportunities for policy transfer. While negative lessons from the German experience reinforced opposition to feed-in tariffs in Morocco, the provision of evidence by German transfer agents likely facilitated the decision for high shares of renewables as part of the Moroccan energy strategy.

These findings show that studies of policy transfer need to go beyond the assessment of whether a specif-

\footnotetext{
52 Moroccan interview partner, MASEN, 11/02/2014, Rabat.
}

ic policy was adopted in another constituency. Insights presented in this article can also provide lessons for the effective design of strategies for "leadership by diffusion" by pioneering countries. Leadership strategies based on basic common orientations, such as deploying more renewable energy, rather than on promoting specific instruments appear promising. In the case of Morocco, as several interview partners underlined, a future German outreach strategy could therefore concentrate on transferring "energy transition soft skills" such as knowledge about how transitions can be managed, communicated, planned and sustained in the long-run.

\section{Acknowledgements}

The author would like to thank Miranda Schreurs, Jens Marquardt, Katharina Hay, as well as two anonymous reviewers for their valuable comments on earlier versions of this article. While carrying out research presented in this article, the author was supported by a doctoral scholarship and a travel grant from the German Ministry for Education and Research administered by the Foundation of German Business (Stiftung der Deutschen Wirtschaft).

\section{Conflict of Interests}

The author declares no conflict of interest. While the author was affiliated with the Secretariat of the German-Moroccan Energy Partnership (GIZ) in parallel to carrying out research for this publication, all research presented in this article was designed and conducted independently by the author as part of her doctoral research project.

\section{References}

Agentur für Erneuerbare Energien. (2014). Großteil der Erneuerbaren Energien kommt aus Bürgerhand. Berlin: Agentur für Erneuerbare Energien. Retrieved from http://www.unendlich-viel-energie.de/media/ file/284.AEE_RenewsKompakt_Buergerenergie.pdf

Agueniou, S. (2013, November 26). Les importations d'électricité augmentent malgré la baisse de la demande. La Vie éco. Retrieved from http://www. lavieeco.com/news/economie/les-importations-delectricite-augmentent-malgre-la-baisse-de-lademande-27461.html

Altmann, C. (2012). Energiewende in Marokko (Akzente (GIZ), N02/2012), 33-35. Eschborn: GIZ. Retrieved from https://www.giz.de/de/downloads/giz2012de-akzente02-energiewende-mexiko.pdf

Amrane, O. (2013, November). Etat d'avancemen et perspectives des énergies renouvelables au Maroc (solaire et éolien): Speech (own notes). CGEM Conference "La transition énergetique", Casablanca Hy- 
att Regency.

Baker, L., Newell, P., \& Phillips, J. (2014). The political economy of energy transitions: The case of South Africa. New Political Economy, 19(6), 719-818. doi:10.1080/13563467.2013.849674

Biedenkopf, K. (2012). Environmental leadership through the diffusion of environmental pioneering policy. In D. R. Gallagher (Ed.), Environmental leadership. A reference handbook (pp. 105-112). Los Angeles: SAGE Publications.

BMU. (2013). Club der Energiewende-Staaten: Kommuniqué. Berlin: BMU. Retrieved from http://www. erneuerbare-energien.de/EE/Redaktion/DE/Down loads/Hintergrund/club-energiewendestaatenkommunique.pdf?_blob=publicationFile \& $v=4$

BMWi. (2012). Rösler und Douiri begründen deutschmarokkanische Energiepartnerschaft: Press release. Berlin: BMWi. Retrieved from http://www.bmwi. de/DE/Presse/pressemitteilungen, did $=495234 . \mathrm{html}$

BMU. (2011). Beschlüsse des Bundeskabinetts zur Energiewende vom 6. Juni 2011. Berlin: BMU. Retrieved from http://www.bmub.bund.de/detailansicht/arti kel/beschluesse-des-bundeskabinetts-zur-energie wende-vom-6-juni-2011

BMWi. (2011). Der Weg zur Energie der ZukunftSicher, bezahlbar und umweltfreundlich: Eckpunkte für ein energiepolitisches Konzept. Berlin: BMWi. Retrieved from http://www.bmwi.de/DE/Themen/ energie, did=405004.html

Bundestag. (1988). Antwort der Bundesregierung auf die Große Anfrage zur Förderung und Nutzung "Erneuerbarer Energiequellen" in der Bundesrepublik Deutschland: Bundestagsdrucksache, (11/2684).

Bundestag. (2014). Gesetz zur grundlegenden Reform des Erneuerbaren-Energien-Gesetzes und zur Änderung weiterer Bestimmungen des Energiewirtschaftsrechts, BgBI 1066.

Busch, P.-O. (2003). Die Diffusion von Einspeisevergütungen und Quotenmodellen: Konkurrenz der Modelle in Europa (FFU-report, No. 03/2003). Berlin. Berlin: FFU. Retrieved from http://edocs.fu-berlin. de/docs/receive/FUDOCS_document_000000007822

Busch, P.-O., \& Jörgens, H. (2005). Globale Ausbreitungsmuster umweltpolitischer Innovationen (FFUreport, No. 02-2005). Berlin: FFU.

Chandler, J. (2009). Trendy solutions: Why do states adopt Sustainable Energy Portfolio Standards? Energy Policy, 37(8), 3274-3281. doi:10.1016/j.enpol. 2009.04.032

Cosbey, A. (2009). Developing country interests in climate change action and the implications for a post2012 climate change regime (No. UNCTAD/ DITC/BCC/2009/2). New York and Geneva: UNCTAD.

Département de l'Environnement. (2009). Plan national de lutte contre le réchauffement climatique. Rabat: Secrétariat d'Etat auprès du Ministère de
l'Energie, des Mines, de l'Eau et de l'Environnement, chargé de l'Eau et de l'Environnement.

Direction de l'Observation et de la Programmation. (n.d.). Chiffres clés du secteur de l'énergie année 2011. Retrieved from http://www.mem.gov.ma/ ChiffresCles/Energie/ChiffreEnergie\%20annuelhtm. html

Dolowitz, D. P., \& Marsh, D. (2000). Learning from abroad: The role of policy transfer in contemporary policy-making. Governance, 13(1), 5.

Eberhard, A., Kolker, J., \& Leigland. (2014). South Africa's renewable energy IPP procurement program: Success factors and lessons. Washington: PPIAF. Retrieved from www.gsb.uct.ac.za/files/PPIAFReport.pdf

Elkins, Z., \& Simmons, B. (2005). On waves, clusters, and diffusion: A conceptual framework. The $A N$ NALS of the American Academy of Political and Social Science, 598(1), 33-51. doi:10.1177/000271620 4272516

Evans, M. (2004). Policy transfer in global perspective. Farnham: Ashgate.

Evans, M. (2009). Policy transfer in critical perspective. Policy Studies, 30(3), 243-268.

Genovese, F., Kern, F., \& Martin, C. (2012). Policy Osmosis: Rethinking diffusion processes when policies have substitutes. Kiel: Kiel University. Retrieved from http://www.cpig.uni-kiel.de/de/research/workingpapers/documents/policy-osmosis-rethinkingdiffusion-processes-when-policies-have-substitutes

GIZ. (2012a). Germany in the Eyes of the World: Key findings of the GIZ survey "Germany viewed from abroad-The implications for international cooperation. Eschborn: GIZ. Retrieved from http://www. agenz.de/data/en-germany-in-the-eyes-of-theworld-2012.pdf

GIZ. (2012b). Energiewende in Marokko. Eschborn: GIZ. Retrieved from http://www.giz.de/de/downloads/ giz2012-de-akzente02-energiewende-mexiko.pdf

Gläser, J., \& Laudel, G. (2010). Experteninterviews und qualitative Inhaltsanalyse: Als Instrumente rekonstruierender Untersuchungen (4. Aufl). Lehrbuch. Wiesbaden: VS Verlag für Sozialwissenschaften.

Graichen, P., Kleiner, M. M., Litz, P., \& Podewils, C. (2015). Die Energiewende im Stromsektor: Stand der Dinge 2014: Rückblick auf die wesentlichen Entwicklungen sowie Ausblick auf 2015 (Analyse). Berlin, Germany: Agora Energiewende.

GTZ. (2009). Energy-policy Framework Conditions for Electricity Markets and Renewable Energies: 16 country analyses. Retrieved from http://www. ecofys.com/files/files/gtz2009-en-terna-analysiscomplete.pdf

Heinze, T. (2011). Mechanism-based thinking on policy diffusion. A review of current approaches in political science (KFG Working Paper Series No. 34). Berlin: Freie Universität Berlin, KFG "The Transformative Power of Europe". Retrieved from http://userpage. 
fu-berlin.de/kfgeu/kfgwp/wpseries/WorkingPaper KFG_34.pdf

Holzinger, K., Jörgens, H., \& Knill, C. (Eds.). (2007). Transfer, Diffusion und Konvergenz von Politiken. Wiesbaden: VS Verlag für Sozialwissenschaften.

Holzinger, K., Knill, C., Heichel, S., \& Sommerer, T. (2010). Theorie und Empirie internationaler Politikkonvergenz: Eine vergleichende Analyse der Umweltpolitik zwischen 1970 und 2000. Opladen: Budrich.

IEA. (2014). Morocco 2014-Energy Policies Beyond IEA Countries. Paris: IEA.

Jacobs, D., Peinl, H., Gotchev, B., Schäuble, D., Matschoss, P., Bayer, B., Kahl, H., Kahles, M., Müller, T., Goldammer, K. (2014). Ausschreibungen für erneuerbare Energien in DeutschlandAusgestaltungsoptionen für den Erhalt der Akteursvielfalt (IASS Working Paper No. September 2014).Potsdam: IASS. Retrieved from http://doi. org/10.2312/iass.2014.015

Jäger, J. (2011). Potentialstudie für photovoltaische Solarenergie für die Regionen Meknès-Tafilalet, Oriental und Souss-Massa-Drâa: für die Deutsche Gesellschaft für Internationale Zusammenarbeit (GIZ) GmbH (Updated version November 2011). Rabat, Eschborn: GIZ.

Jänicke, M. (2005). Trend-setters in environmental policy: The character and role of pioneer countries. European Environment, 15(2), 129-142.

Joas, F., Pahle, M., \& Flachsland, C. (2014). Die Ziele der Energiewende: Prioritäten: Eine Kartierung der Prioritäten. ifo-Schnelldienst, 09/2014, 6-11.

KfW. (2014). Marokko-Solarenergie: Energiewende auf marokkanisch. Frankfurt: KfW. Retrieved from https: //www.kfw-entwicklungsbank.de/InternationaleFinanzierung/KfW-Entwicklungsbank/Sektoren/ Energie/Projektbeispiele/Marokko-Solarenergie

Klimaretter. (2007). Marokko importiert das EEG. Berlin: GutWetter Verlag. Retrieved from http://www.klima retter.info/klimacamp-blog-mainmenu-298?start $=40$

Klingler-Vidra, R. (2014). All politics is local. Sources of variance in the diffusion of venture capital policies. London: London School of Economics.

Konrad-Adenauer-Stiftung. (2013). Wahrnehmung der deutschen Energiewende in Schwellenlaendern: Ergebnisse einer qualitativen Expertenbefragung in Brasilien, China und Suedafrika. Berlin: KonradAdenauer-Stiftung. Retrieved from http://www. kas.de/wf/de/33.34940

Konrad-Adenauer-Stiftung. (2014). Wahrnehmungen der deutschen Energiewende in Schwellenländern: Teil 2 - Ergebnisse einer qualitativen Expertenbefragung in Russland und Indien. Berlin: KonradAdenauer-Stiftung. Retrieved from http://www. kas.de/wf/de/33.38988

Krause, F., Bossel, H., Müller-Reißmann, K. F., \& MüllerReissmann, K.-F. (1980). Energie-Wende: Wachstum und Wohlstand ohne Erdöl und Uran: Ein AlternativBericht des Öko-Instituts, Freiburg (3rd ed.). Frank- furt am Main: Fischer.

Kreycik, C., Couture, T., \& Karlynn, C. (2011). Innovative feed-in tariff designs that limit policy costs (NREL Report No. TP-6A20-50225). Golden: NREL.

Malnes, R. (1995). "Leader" and "entrepreneur" in international negotiations: A conceptual analysis. European Journal of International Relations, 1(1), 87112.

MAP. (2014, January 3). Adoption de l'accord de coopération franco-marocain pour l'utilisation pacifique de l'énergie nucléaire. Aujourd'hui le Maroc. Retrieved from http://www.aujourdhui.ma/une/ actualite/adoption-de-l-accord-de-cooperationfranco-marocain-pour-I-utilisation-pacifique-de-Ienergie-nucleaire-107009\#.VRtwVLrpjdl

Marsh, D., \& Sharman, J. (2009). Policy diffusion and policy transfer. Policy Studies, 30(3), 269-288.

MASEN. (2010). Le Plan Solaire Marocain. Rabat: MASEN. Retrieved from http://masen.org.ma/ index.php?ld=42\&lang=fr\#/_

Matisoff, D. C. (2008). The adoption of state climate change policies and renewable portfolio standards: Regional diffusion or internal determinants? Review of Policy Research, 25(6), 527-546.

Matisoff, D., \& Edwards, J. (2014). Kindred spirits or intergovernmental competition? The innovation and diffusion of energy policies in the American states (1990-2008). Environmental Policy, 23(5), 795-817.

Maubach, K.-D. (2013). Energiewende: Wege zu einer bezahlbaren Energieversorgung. SpringerLink : Bücher. Wiesbaden: VS Verlag für Sozialwissenschaften.

Meseguer, C. (2005). Rational learning and bounded learning in the diffusion of policy innovations. Working Paper: Vol. 316. Notre Dame, Ind: Helen Kellogg Institute for International Studies.

Ministère de l'Energie, Mines de l'Eau et de l'Environnement. (2013a). Allocution du Dr. Abdelkader Amara: Conférence-débat sur la transition énergétique le mercredi 27 novembre 2013. Rabat: MEMEE. Retrieved from http://www.mem.gov.ma/ SitePages/Discours/Disc271113.pdf

Ministère de I'Energie, Mines de l'Eau et de l'Environnement. (2013b). La nouvelle Stratégie Energétique Nationale: Bilan d'étape. Rabat: MEMEE.

Mitchell, C. (2008). The political economy of sustainable energy. Energy, climate, and the environment series. Basingstoke, New York: Palgrave Macmillan.

Müller, F., \& Kals, E. (2004). Q-sort technique and Qmethodology-Innovative methods for examining attitudes and opinions. Forum: Qualitative Social Research, 5(2), Art. 34.

ONE. (2010). Projet Marocain Eolien Integré. Casablanca: ONE. Retrieved from http://www.one.org.ma/ $\mathrm{fr} /$ pages/Program_mar_ener_eol.asp?esp =2\&id1=8 \&id2 $=70 \& t 2=1$

ONE. (2014). Production éolienne. Casablanca: ONE. Retrieved from http://www.one.org.ma/fr/pages/inter 
ne. $\operatorname{asp}$ ?esp $=2 \& \mathrm{id} 1=5 \& \mathrm{id} 2=54 \& \mathrm{id} 3=44 \& \mathrm{t} 2=1 \& \mathrm{t} 3=1$

Osianowski, R.-P. (1997). Internationale Erfahrungen bei der Durchführung von SEP der GTZ in Marokko. In H. G. Brauch (Ed.), Energiepolitik. Technische Entwicklung, politische Strategien, Handlungskonzepte zu erneuerbaren Energien und zur rationellen Energienutzung (pp. 311-328). Berlin: Springer.

Pegels, A. (2014). Lessons for successful green industrial policy. In A. Pegels (Ed.), Routledge studies in ecological economics: Vol. 34. Green industrial policy in emerging countries (pp. 179-186). London: Routledge.

PWMSP Project Consortium. (2013). Politique énergétique durable Feuille de Route-Maroc (Traduction du 3ème Draft). Rabat: PWMSP Consortium. Retrieved from http://www.pavingtheway-msp.eu/ index.php?option=com_downloads\&task=category \&cid $=19 \&$ Itemid $=150$

REN21 Secretariat. (2012). Renewables 2012: Global Status Report. Paris: REN 21 Secretariat. Retrieved from http://www.ren21.net/Portals/0/documents/ Resources/GSR2012_low\%20res_FINAL.pdf

Roller, G., Lefèvre, M., Wirtz, J., Schmidt-Sercander, B., Eichhammer, W., Ragwitz, M., Klein, A., Cremer, C., Keller, S., Resch, G., \& Mouline, S. (2007). Etude sur le cadre organisationnel, institutionnel et législatif pour la promotion des énergies renouvelables. Retrieved from http://www.giz.de/en/worldwide/20191.html

Rose, R. (1991). What is lesson-drawing? Journal of Public Policy, 11(01), 3-30.

Sidki, W. (2011). Le Programme de 1 Million de toits: Une solution énergétique possible pour l'introduction de la technologie photovoltaïque à grande échelle au Maroc. Berlin: HTW. Retrieved from https:// www.giz.de/de/downloads/giz2011-fr-programmemillion-de-toits.pdf

Simmons, B., \& Elkins, Z. (2004). The globalization of liberalization: Policy diffusion in the international political economy. American Political Science Review, 98(01), 171-189.

Smithwood, R. B. (2011). Competition and collaboration in renewable portfolio standard adoption and policy design: Lessons from New England (Energy, Climate, and Innovation Discussion Paper). Medford: Tufts University.

Sommerer, T. (2011). Können Staaten voneinander lernen?: Eine vergleichende Analyse der Umweltpolitik in 24 Ländern (1st ed.). Wiesbaden: VS Verlag für Sozialwissenschaften.

Steinbacher, K., \& Pahle, M. (2015). Leadership by diffusion and the German Energiewende. PIK Discussion Paper, February 2015. Potsdam: PIK. Retrieved from https://www.pik-potsdam.de/members/pahle /dp-ew-leadership-2015.pdf

Rat für nachhaltige Entwicklung. (2013). SustainabilityMade in Germany: The second review by a group of international peers, commissioned by the German Federal Chancellery. Berlin: Rat für nachhaltige Entwicklung/German Council for Sustainable Development.

Stone, D. (2004). Transfer agents and global networks in the "transnationalization" of policy. Journal of European Public Policy, 11(3), 545-566.

Stoutenborough, J. W., \& Beverlin, M. (2008). Encouraging pollution-free energy: the diffusion of state net metering policies. Social Science Quarterly (Wiley-Blackwell), 89(5), 1230-1251. Retrieved from 10.1111/j.1540-6237.2008.00571.x

Tews, K. (2002). Der Diffusionsansatz für die vergleichende Policy-Analyse. Wurzeln und Potenziale eines Konzepts.: Eine Literaturstudie (FFU Report, 22002).Berlin: FFU.

Vasseur, M. (2014). Convergence and divergence in renewable energy policy among US states from 1998 to 2011. Social Forces, 92(4), 1637-1657. doi:10. 1093/sf/sou011

Vidican, G., Böhning, M., Burger, G., de Siqueira Regueira, Elisa, Müller, S., \& Wendt, S. (2013). Achieving inclusive competitiveness in the emerging solar energy sector in Morocco (Studies No. 79). Bonn: Deutsches Institut für Entwicklungspolitik. Retrieved from http:// www.die-gdi.de/uploads/media/Studies_79.pdf

Weidner, H., \& Mez, L. (2008). German climate change policy: A success story with some flaws. The Journal of Environment \& Development, 17(4), 356-378.

\section{About the Author}

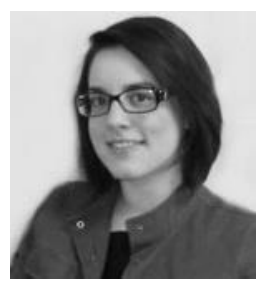

\section{Karoline Steinbacher}

Karoline Steinbacher is a doctoral candidate at the Environmental Policy Research Centre (FFU) at Freie Universität Berlin. Her PhD research focuses on lesson-drawing from the German Energiewende in Morocco, South Africa, and California, and on the role of "leader countries" in processes of policy transfer. Before joining FFU as a PhD candidate in late 2012, Karoline worked as a junior analyst for the Austrian energy regulation authority. 


\section{Annex}

Table A1. Overview of ranking outcomes.

\begin{tabular}{|c|c|c|c|c|c|c|c|c|c|c|c|c|c|c|}
\hline Nat & $\mathrm{N}^{\circ}$ & Liber & Clim & Jobs & Decen & Price & Indep & Nucl & Indu & Lead & Export & Invest & Societ & Int \\
\hline D & 11 & 0 & 3 & 1 & 3 & 1 & 1 & 4 & 1 & 0 & 2 & 2 & 3 & 0 \\
\hline D & 12 & 2 & 4 & 3 & 6 & 1 & 1 & 5 & 4 & 0 & 5 & 3 & 4 & 5 \\
\hline D & 13 & 7 & 6 & 2 & 0 & 1 & 1 & 7 & 2 & 0 & 3 & 3 & 6 & 3 \\
\hline D & 14 & 3 & 4 & 2 & 5 & 1 & 1 & 5 & 2 & 4 & 2 & 3 & 5 & 4 \\
\hline D & 15 & 6 & 0 & 4 & 0 & 1 & 1 & 9 & 9 & 4 & 4 & 4 & 0 & 4 \\
\hline D & 16 & 2 & 4 & 3 & 6 & 1 & 1 & 5 & 4 & 0 & 5 & 3 & 4 & 5 \\
\hline D & 17 & 13 & 13 & 2 & 13 & 13 & 1 & 13 & 2 & 2 & 2 & 2 & 13 & 13 \\
\hline D & 18 & 0 & 5 & 1 & 0 & 3 & 2 & 0 & 1 & 4 & 6 & 0 & 0 & 5 \\
\hline D & 19 & 13 & 1 & 2 & 11 & 8 & 6 & 12 & 4 & 3 & 9 & 7 & 5 & 10 \\
\hline D & 110 & 8 & 5 & 2 & 6 & 8 & 1 & 6 & 3 & 6 & 4 & 5 & 7 & 4 \\
\hline 1 & $\mid 11$ & 2 & 3 & 1 & 0 & 3 & 1 & 0 & 3 & 2 & 2 & 1 & 3 & 2 \\
\hline 1 & 112 & 7 & 7 & 4 & 8 & 3 & 2 & 8 & 6 & 4 & 6 & 1 & 5 & 5 \\
\hline I & 113 & 0 & 5 & 3 & 0 & 5 & 1 & 0 & 4 & 6 & 2 & 4 & 6 & 0 \\
\hline 1 & 114 & 0 & 0 & 3 & 0 & 5 & 1 & 0 & 2 & 0 & 0 & 0 & 0 & 0 \\
\hline 1 & $\mid 15$ & 7 & 2 & 6 & 3 & 0 & 1 & 0 & 6 & 5 & 2 & 4 & 0 & 0 \\
\hline 1 & 116 & 0 & 4 & 2 & 0 & 8 & 1 & 0 & 2 & 0 & 8 & 2 & 0 & 0 \\
\hline 1 & 117 & 8 & 11 & 10 & 11 & 6 & 4 & 12 & 10 & 9 & 12 & 8 & 10 & 11 \\
\hline$M$ & 118 & 0 & 5 & 4 & 0 & 0 & 1 & 0 & 2 & 6 & 3 & 0 & 0 & 0 \\
\hline$M$ & $\mid 19$ & 9 & 8 & 3 & 11 & 6 & 5 & 10 & 4 & 2 & 7 & 13 & 1 & 12 \\
\hline$M$ & 120 & 1 & 3 & 9 & 9 & 7 & 1 & 9 & 9 & 4 & 2 & 5 & 7 & 6 \\
\hline$M$ & 121 & 6 & 2 & 1 & 0 & 4 & 0 & 0 & 5 & 0 & 5 & 0 & 3 & 5 \\
\hline$M$ & 122 & 6 & 1 & 1 & 5 & 0 & 2 & 0 & 3 & 1 & 0 & 4 & 1 & 0 \\
\hline$M$ & 123 & 5 & 4 & 4 & 5 & $\underline{4}$ & 2 & 4 & 3 & 1 & 3 & 3 & 4 & 3 \\
\hline$M$ & 124 & 11 & 8 & 3 & 6 & 2 & 1 & 0 & 5 & 9 & 12 & 4 & 10 & 7 \\
\hline$M$ & 125 & 11 & 4 & 3 & 7 & 13 & 2 & 1 & 9 & 6 & 12 & 10 & 5 & 8 \\
\hline$M$ & 126 & 12 & 6 & 2 & 10 & 7 & 1 & 13 & 6 & 6 & 13 & 2 & 12 & 12 \\
\hline$M$ & 127 & 3 & 4 & 4 & 2 & 1 & 2 & 0 & 5 & 4 & 3 & 6 & 1 & 0 \\
\hline$M$ & 128 & 3 & 1 & 2 & 3 & 2 & 1 & 4 & 2 & 3 & 2 & 1 & 4 & 2 \\
\hline$M$ & 129 & 12 & 8 & 5 & 7 & 2 & 1 & 13 & 6 & 9 & 10 & 4 & 3 & 11 \\
\hline$M$ & 130 & 1 & 7 & 3 & 4 & 3 & 2 & 8 & 3 & 6 & 5 & 3 & 7 & 4 \\
\hline$M$ & 131 & 9 & 6 & 3 & 10 & 1 & 2 & 11 & 5 & 12 & 8 & 4 & 7 & 13 \\
\hline$M$ & 132 & 8 & 7 & 3 & 0 & 2 & 2 & 0 & 4 & 10 & 6 & 5 & 1 & 9 \\
\hline$M$ & 133 & 7 & 6 & 4 & 0 & 0 & 1 & 0 & 3 & 5 & 8 & 0 & 0 & 0 \\
\hline$M$ & 134 & 12 & 6 & 2 & 13 & 1 & 3 & 10 & 7 & 5 & 11 & 4 & 8 & 9 \\
\hline$M$ & 135 & 3 & 1 & 2 & 3 & 2 & 1 & 4 & 2 & 3 & 2 & 1 & 4 & 2 \\
\hline$M$ & 136 & 0 & 3 & 2 & 0 & 4 & 1 & 0 & 2 & 6 & 7 & 5 & 0 & 0 \\
\hline$M$ & 137 & 8 & 3 & 5 & 13 & 2 & 1 & 12 & 4 & 10 & 6 & 7 & 9 & 11 \\
\hline$M$ & 138 & 3 & 5 & 4 & 10 & 1 & 2 & 0 & 6 & 8 & 9 & 7 & 0 & 0 \\
\hline$M$ & 139 & 4 & 0 & 3 & 9 & 8 & 7 & 0 & 2 & 6 & 1 & 5 & 0 & 0 \\
\hline$M$ & 140 & 9 & 8 & 2 & 0 & 0 & 6 & 0 & 1 & 3 & 7 & 4 & 5 & 0 \\
\hline
\end{tabular}

Notes: $\mathrm{D}=$ German organizations, I = International, $\mathrm{M}=$ Moroccan, Liber = Liberalization, Climate = Climate protection, Jobs = Job creation, Decen $=$ Decentralization, Price $=$ Affordable electricity prices, Indep = energy independence, Nucl $=$ avoiding nuclear energy, Indu = creating an industry, Lead = leadership, Export = electricity exports, Invest = attracting investors, Socie = societal projects, Intl = expectation of international community 